\title{
THE ROLE OF GENDER AND SITUATIONAL FACTORS IN WINE CONSUMPTION OF GENERATIONY
}

Jasmina Dlačić, Selma Kadić-Maglajlić *

\section{Abstract}

The purpose of this study is to analyze the factors influencing wine consumption of Generation $Y$ consumers in the context of two countries from South-Eastern Europe (Bosnia -Herzegovina, and Croatia). Analysis reveals that self-expression, sociability, tradition and food are significant predictors of wine consumption. Multivariate regressions have been applied in order to explain the influences of the abovementioned factors on wine consumption. Research findings show that specific gender and situational differences exist in the wine consumption behaviour of Generation $Y$. This paper discusses theoretical, empirical and practical implications, and offers ideas for further research.

\section{Keywords: wine consumption, wine consumption motivators, Generation Y, Bosnia and Herzegovina, Croatia}

JEL classification: M31
South East European Journal of Economics and Business Volume 8 (1) 2013, 53-61

DOI: $10.2478 /$ jeb-2013-0008

\section{INTRODUCTION}

Wine is becoming a lifestyle beverage for all generations (Bruwer, Saliba \& Miller, 2011), but the image of wine differs among age cohorts (Olsen, Thach \& Nowak, 2007). Bearing in mind that each generation has specific values that lead to different behaviours (Inglehart, 1997), age segmentation in the wine business is becoming increasingly important. This can be explained by the fact that wine consumption increases with age, experience and with the maturation of a person's palette (Quester \& Smart, 1996; Stanford, Bailey \& Rowley, 2008).

Young consumers, especially Generation Y, born in the period between 1977 and 1999 (Lancaster \& Stillman, 2003) are experiencing a growing trend of interest in the wine market. However, they are still inexperienced, confused and overwhelmed by having to choose wine (Wine Intelligence, 2010). Euromonitor International (2012) suggests that within the overall alcoholic beverage consumption of Generation $Y$, wine seems to play a minor role. However it does increase later. As Generation $Y$ is getting older the wine industry is aware of the need to pay more attention to this segment (Kevany, 2008; Mueller, Remaud \& Chabin, 2011) if they would like to ensure market growth in the future. Peskett (2006) confirmed that in the coming years Generation $Y$ members will become increasingly important as wine consumers. Generation $Y$ presents an increasing market for alcoholic beverages, with wine in particular benefiting from the fact that it is viewed as fashionable and reflective of a sophisticated image (Euromonitor International, 2012). Furthermore, Generation $Y$ includes many future business people and wine producers should also take into account different factors that influence their habits regarding consuming wine in business situations. However, Charters et al. (2011) assert that little academic research has been carried out regarding the general wine preferences of Generation $\mathrm{Y}$ - most of which has focused on the USA.

Atkin, Nowak and Garcia (2007) acknowledge that gender plays an important role in the wine information search as well as in consequent buying behaviour. According to them, males and females show different patterns and this information should be taken into account when approaching

\footnotetext{
* Jasmina Dlačić, Ph.D.

Senior Assistant

University of Rijeka, Faculty of Economics

E-mail: jasmina.dlacic@ri.t-com.hr

Selma Kadić-Maglajlić, Ph.D.

Assistant Professor

University of Sarajevo, School of Economics and Business

E-mail: selma.kadic@efsa.unsa.ba
} 
customers. Therefore, changes in marketing and advertising strategies are required in order to take generational specificities into account (Angoli, et al 2011), as well as consumption situations and gender differences that drive consumers' wine consumption motives. Bearing in mind that factors which influence consumer behaviours are cultural, social, personal and psychological (Kotler and Keller, 2008), one of the goals of this study is to examine the influence of age and gender as a part of personal-demographic factors.

Globally, the wine market and wine consumption are growing (OIV, 2012), with consumption in EU countries accounting for around $65 \%$ of the world wine market. Within agricultural production, wine production has GDP value added ranging from 3.6\% for Bosnia and Herzegovina and $6.4 \%$ for Croatia (FAQ, 2012, EC 2012). These rates are close to the average rate of wine production contributing GDP value added within the EU-27 countries, which is $3.9 \%$. Nonetheless, wine production is identified as an important sector within both national economies. National wine sector development strategies in both countries place emphasis on the production of high quality wine, the development of specialized wine marketing programs for small local wine producers and the promotion of local high quality wine to new markets. Therefore, wine production is seen as an important contributor to economic development in Bosnia and Herzegovina and Croatia. Given the above, we contend that it is important to examine the attributes of wine consumption in local markets, with special focus on Generation $\mathrm{Y}$, which is a growing wine target market and whose tastes are moving towards appreciation of wine as a drink.

The main purpose of the paper is to explain the antecedents of wine consumption in different purchase situations, bearing in mind the gender differences of Generation Y. Hence, this study should help practitioners to create a more appropriate promotional tool in order to adequately target male and female Generation $Y$ consumers in the context of two South-Eastern European countries.

The paper is organized into the following sections. First, a theoretical background and hypotheses development on wine consumption motives are offered. This section is followed by empirical research and hypotheses testing. The final part of the paper consists of a conclusion, proposals for further research and a discussion of the study's limitations.

\section{CONCEPTUAL BACKGROUND ON WINE CONSUMPTION PATTERNS}

\subsection{Motivational Influences}

To support the growing trend of the world wine market, wine consumption should be introduced to young consumers during the critical years in their late teens to their earlyto-mid-20s, since during those years they form consumption habits for life (Bruwer, 2004). Different motives drive wine consumption. Brunner and Siegrist (2011) identified several groups of wine consumption motives such as self-expression, recreation, sociability, health, style, food, pleasure, tradition, fun and intellectual challenge. Furthermore, these wine consumption motives differ across situations. Vrontis and Papasolomou (2007) found that wine tasting events, word-of-mouth and wine exhibitions are the most important factors influencing consumers' behaviour and in shaping consumer perception and purchase decisions. Hence, researchers acknowledge that different situations shape wine consumption behaviour (Brunner \& Siegrist, 2011; Dubow, 1992; Charters, 2006). Wine is consumed because a person wants to be socially accepted or to emphasize her/ his status. It aids the aesthetic perception of a person who consumes wine. Furthermore, wine consumption also ensures relaxation and creates a nice, relaxing environment. It aids socializing, connects people and helps establishing sociability. Moreover, for some taking a glass of wine or consuming wine represents connection with tradition. Wine is also considered to enhance hedonic pleasure and is usually taken as a drink that enhances the taste of food. It also represents an intellectual challenge because of the complexity of its tastes (Kolyesnikova et al., 2008).

Generational cohorts are one of the least understood marketing dynamics (Bruwer et al., 2011). Mueller et al. (2011) proved that Generation $Y$ is more oriented towards hedonic success and status and less oriented towards social values. Therefore, it is most promiscuous in its alcoholic beverage consumption, but still having a positive disposition towards wine (Nielsen, 2007; Thach \& Olsen, 2006).

\subsection{Consumption Situation Influences}

Olsen et al. (2007) claimed that Generation Y perceives wine as a social beverage, playing an important role in social occasions for this generation. Young consumers are more likely to consume alcoholic beverages at pubs, bars and in restaurants, compared to older generations who mainly consume alcohol at home (Teagle et al., 2010). Angoli et al. (2011) introduced three levels attributed to the company in which one consumes wine: alone, with family and with friends.

Furthermore, intended usage and consumption situations have a significant influence on purchasing behaviour (Ritchie, 2009). This is reflected in the choice of different buying places when wine is bought as a gift, that is, on special occasions, versus everyday wine that is usually consumed with meals with a family or partner. Also, different explicit and implicit cues influence wine selection depending on the consumption situation (Atkin, Nowak \& Garcia, 2007). According to Olsen, Thach and Nowak (2007) generational differences are also evident in different wine consumption situations, indicating that Generation $Y$ will consume wine more than other generations at bars and formal celebrations. Also, the influence of reference groups such as friends, family and co-workers is more evident in the youngest generational cohort, Generation Y. Young people certainly prefer consuming wine with friends or family. Therefore, this research compares the choices that are made therein with choices that are influenced by family and those that spring from individual decisions, like special occasions. 
H1: Generation Y exhibits different wine consumption motivators depending on wine consumption occasions.

\subsection{Gender Influences}

Male and female consumers have different perspectives on evaluating products and services, information searches, decision processes and attitudes towards marketing mix strategies (Gunay \& Baker, 2011). These differences result from the biological distinction between male and female (Garst \& Bodenhausen, 1997).

Certain products are perceived to be more gender-specific than others, meaning that individuals with stronger masculine or feminine identities tend to associate with them if they appeal to this aspect of their identity (Hall et al., 2001). Spawton (2000) went as far as to state that wine has been generally perceived as a feminine beverage. This conclusion is supported by research Baber et al. (2006) who identify white wine as female drink. A recent qualitative study conducted by Charters et al., (2011) has confirmed that Generation Y perceives champagne and sparkling wine as a woman's drink. Moreover, Richie (2009) asserts that even though wine buying is considered a traditional male role, actually more females buy wine.

Other studies (Schamberg, 2002; Robinson, 2004; Low, 2001; Hoffman, 2004) have examined the gender influence of wine behaviour. However, as Bruwer et al. (2011) argue, these studies did not probe whether the wine behaviours identified through gender research have a relationship with age subcultures (Generation Y, for example).

This also highlights the issue that gender plays an important role in wine segmentation, in addition to age. Atkin, Nowak and Garcia (2007) suggest that a good starting point when evaluating how consumers make wine buying decisions may be looking at demographic and lifecycle variables, with gender in particular as a starting point. Therefore, this research compares gender influences in wine consumption motivators according to different consumption situations.

H2: Generation Y's wine consumption motivators under different wine consumption occasions demonstrate gender influence.

\section{EMPIRICAL RESEARCH}

Wine consumption in Bosnia-Herzegovina grew 3\% in volume during 2010, totalling 13 million litres off-trade and 2 million litres on-trade, implying that an increased interest among consumers for wine culture is evident (Euromonitor International, 2010a). Female consumers aged 18-30 drive the on-trade consumption of wine. Alcohol consumption per capita is at 7.1 litres, while wine consumption is 1.2 litres per capita (WHO, 2014). This data raises the possibly for increasing the wine consumption rate among youngsters, as wine has a lower level of alcohol than spirits and hence can be considered a more appropriate alcoholic drink. Euromonitor International (2010a) assesses that
Bosnia-Herzegovina consumers will take an increasing interest in wine culture in the near future, being influenced by subtle media campaigns using television, magazines and the Internet. Even if total wine production in 2010 was at a level of $54000 \mathrm{HL}$ (FAO, 2012), the geographical position of Bosnia and Herzegovina is what gives importance to the local wine industry as a facilitator of economic development.

Croatia has a long tradition of alcohol consumption, with a per capita consumption of 12.2 litres in 2010, where wine comprised 6.6 litres (WHO, 2010). Generation Y members in Croatia do not usually drink wine with meals and tend to prefer wine mixed with Coca-Cola when in pubs or bars. Women have begun to drink non-grape wine, especially blackberry wine, because of the perceived health benefits of this type of beverage (Euromonitor International, 2012). In urban areas, wine is often replaced by beer, though those with more disposable income consume wine with their main meals. Total wine production in Croatia in 2010 was at 143300 HL (Gain report, 2014). Different regions are characterized by small local producers that mostly sell wine on the local market, with an emphasis on introducing wine marketing and producing high quality wine can help enhance local development.

Generation $Y$ in both countries comprises more then $20 \%$ of the total population, Bosnia-Herzegovina with 22.2\% (ASBH, 2013) and Croatia 25.43\% (CBS, 2013). Most of them spent their early childhood in the same country, the former Yugoslavia, and had a melting pot experience that included other cultures and nationalities. Their direct and indirect war experience and the quick adoption of new ways of thinking, as well as economic and political crises, have shaped the way they perceive world around them. They are team-oriented and build strong relationships with friends, while having both a strong awareness of the environment they live in and an aversion to accepting universal truths (PWC, 2013). Others argue that Generation Y lack universally accepted attitudes and behaviour around the world except in USA and Western Europe. However Generation Y attitudes and behaviour in Bosnia-Herzegovina and Croatia and their alcohol consumption habits are relatively similar (PWC, 2013).

Alcohol consumption in different religions is diversely perceived. Alcohol consumption is sometimes against cultural norms, especially in countries with primarily Muslim inhabitants. In Bosnia-Herzegovina, Muslims constitute 45\%, Orthodox Christians 36\% and Roman Catholics $15 \%$ of the population (US Department of state, 2010). In Croatia Roman Catholics constitute $86.28 \%$ of the population, Orthodox Christians 4.4\%, Muslims $1.47 \%$ and others $7.8 \%$ (CBS, 2013). Still, alcohol consumption in Bosnia and Herzegovina is quite high (7.1 litres per capita) compared to more traditional Muslims societies, where alcohol consumption is around 1.1 litres per capita (WHO, 2014). Hence, all of this contributes toward the validity of researching both countries together. 


\subsection{Data Collection}

To test the proposed hypotheses, field research was conducted in Bosnia-Herzegovina and Croatia. Our research used a highly structured questionnaire for data collection. A non-probability sampling accompanied with a snowball technique was used. Usage of the snowball technique was appropriate because of the sensitivity of the researched topic (Hair et al., 2009), that is, personal alcohol consumption habits. A self-administered online survey was used. As a criterion for identifying participants who could give reliable answers, the first question of the survey determined whether respondents drank wine more than once a month, which if were the case made them eligible to participate in the survey. In total 329 fully completed questionnaires were collected.

Following the definition of Generation $Y$ given by Lancaster and Stillman (2003), the birth years of respondents was taken as a second filter variable. Consequently, 295 out of the 329 collected questionnaires were included in the subsequent research on Generation Y. Sample characteristics are presented in Table 1.

The questionnaire included questions about wine consumption habits and reasons for consuming wine. In defining reasons for wine consumption, different authors were consulted. Items from Brunner and Siegrist (2011), Dubow (1992), Charters (2006) and Thach and Olsen (2004) were used. The survey instrument was developed in English and then translated into the local language. Furthermore, all statements were measured on a five-point Likert scale, where 1 indicated strongly disagree, and 5 indicated strongly agree.

We performed invariance tests across the two samples in line with the literature (e.g., Steenkamp \& Baumgartner, 1998). The results of invariance tests confirmed that configural, metric and scalar invariances existed across the BosniaHerzegovinian and Croatian samples, suggesting that items were equally reliable across both samples. In addition, we also conducted an independent samples t-test to examine differences in responses coming from the two countries. No significant differences were identified, suggesting that the two samples could be examined together. Therefore, we merged our data into single file for further analysis. To analyze results, the SPSS 20.0 and LISREL 8.80 software packages were used. Multivariate regressions were conducted to test the posited hypotheses.

\subsection{Measurement Model Assessment}

For determining the underlying structure of wine consumption motivators an explorative factor analysis (EFA) was firstly performed. Common factor analysis using principal axis factoring in SPSS with oblimin rotation was used, according to the suggestion of Hair et al., (2009). The KMO measure and Bartlett test of sphericity were satisfactory and the exploratory factor analysis was further examined. Heavily cross-loaded items were excluded from the analysis and are not presented in the following tables. While checking for factor reliability, items with low item-to-total correlations were also removed from the factors, as keeping them does not assure additional insight into constructs used in the research. Furthermore, to check the internal structure of the wine consumption motivators under examination, and to check their internal consistency, a confirmatory factor analysis (CFA) using LISREL 8.80 was done. In this analysis the maximum likelihood method is used. Results from both factor analyses are presented in Table 2.

Analysis revealed that four different motivators in the wine consumption process exist among respondents. These four factors are sociability, self-expression, tradition and food. Together they explain $76.93 \%$ of the variance, meaning that they adequately represent the different wine consumption habits of Generation Y. This shows that through exploring wine consumption habits with sociability, self-expression, tradition and food it is possible to identify different perspectives and motivators in wine consumption patterns.

In addition, all of the composite reliabilities are above the suggested minimal threshold of 0.6 (Bagozzi \& Yi, 1988 in Diamantopoulos \& Siguaw, 2000). The minimal value for average variances extracted (AVE) should be 0.5 (Fornell \& Larcker, 1981). AVEs for the three researched constructs are above the suggested minimal value. The sociability factor falls a little lower value than the 0.5 threshold. Nevertheless, we used these constructs for our research, as the sociability factor is suggested to be an important influence factor among young consumers (Olsen et al., 2007). Hence, the suggested measurement variables represent reliable measures for proposed constructs. All of the t-values of the loadings of measurement variables on the respective latent constructs were statistically significant and above the 0.5 value (Anderson, Gerbing, 1988). Also, AVE values for latent constructs are for three out of the four latent constructs greater than 0.5 (MacKenzie, Podsakoff \& Podsakoff, 2011). Therefore, bearing in mind the lower validity of the sociability factor, it can be concluded that convergent validity is

Table 1. Research sample characteristics

\begin{tabular}{|l|l|l|}
\hline & Bosnia and Herzegovina & Croatia \\
\hline Sex & $59.8 \%$ female & $69.4 \%$ female \\
\hline Age group & $67 \% ; 21-30$ years & $37.7 \% 21-30$ years \\
\hline Marital status & $40.2 \%$ in a relationship & $50.3 \%$ in a relationship \\
\hline Education level & $8.9 \%$ high school & $52.5 \%$ high school \\
& $38.4 \%$ first Bologna level & $30.6 \%$ first Bologna level \\
& $52.7 \%$ master's or higher level degree & $16.9 \%$ master's or higher level degree \\
\hline
\end{tabular}


Table 2. Factor and Reliability Analysis Results for Wine Consumption Motivators

\begin{tabular}{|c|c|c|c|c|c|c|}
\hline \multirow[b]{2}{*}{ Items } & \multicolumn{2}{|c|}{ CFA } & \multicolumn{4}{|c|}{ EFA - Factors } \\
\hline & Loadings & t-value & Sociability & $\begin{array}{l}\text { Self- } \\
\text { expression }\end{array}$ & Tradition & Food \\
\hline To be respected & 0.935 & Fixed & & -0.934 & & \\
\hline $\begin{array}{l}\text { Because consuming wine testifies to a } \\
\text { mature personality }\end{array}$ & 0.887 & 20.107 & & -0.902 & & \\
\hline To be distinctive & 0.733 & 15.309 & & -0.710 & & \\
\hline Because it aids socializing & 0.594 & Fixed & 0.682 & & & \\
\hline Because it creates a nice atmosphere & 0.819 & 6.112 & 0.699 & & & \\
\hline $\begin{array}{l}\text { Because a glass of wine belongs with a } \\
\text { nice meal }\end{array}$ & 0.720 & Fixed & & & & -0.709 \\
\hline $\begin{array}{l}\text { Because it creates a special dining } \\
\text { ambience }\end{array}$ & 0.910 & 8.047 & & & & -0.827 \\
\hline Because of my cultural background & 0.861 & Fixed & & & 0.886 & \\
\hline Because it is a tradition in my family & 0.883 & 13.268 & & & 0.910 & \\
\hline For ritual & 0.517 & 8.792 & & & 0.409 & \\
\hline Mean & & & 7.01 & 4.27 & 6.53 & 6.91 \\
\hline Composite reliability $(\rho c)$ & & & 0.608 & 0.937 & 0.753 & 0.738 \\
\hline Average variance extracted ( $\rho v)$ & & & 0.443 & 0.834 & 0.516 & 0.589 \\
\hline \multicolumn{7}{|l|}{ Correlations } \\
\hline Sociability & & & 1 & $0.276^{* *}$ & $0.250^{* *}$ & $0.362^{* *}$ \\
\hline Self-expression & & & & 1 & $0.325^{* *}$ & $0.135^{*}$ \\
\hline Tradition & & & & & 1 & $0.353^{* *}$ \\
\hline Food & & & & & & 1 \\
\hline
\end{tabular}

Note: ${ }^{*}{ }^{* *}$ significant at $<0.05$ and $<0.001$ level, respectively

present. Discriminant validity is also present as correlations among latent constructs exhibit low to moderate values (MacKenzie, Podsakoff \& Podsakoff, 2011). Hence, according to CFA all identified latent constructs have adequate validity and reliability to be used in further analysis.

These results suggest that different drivers of wine consumption are present among Generation Y. Wine is consumed to enhance sociability through socializing and to create a pleasant atmosphere. Olsen et al. (2007) as well as Dubrow (1992) argue that this socialization factor is very much expressed in Generation $Y$ consumers as they are under reference groups' influence and therefore consume wine to help them socialize. Identifying the sociability factor in describing Generation $Y$ wine consumption behaviour will help researchers to identify the extent to which other individuals help create an adequate atmosphere that helps perceiving wine as an important ingredient of a pleasant community. Other characteristics related to consuming wine are connected to a person's desire to be perceived differently. These characteristics are grouped under the selfexpression construct. The desire to be respected and distinctive motivates individuals to consume wine. Individuals also consume wine due to their cultural background or family traditions. Hence, tradition also represents one of the motivators of wine consumption (Chaters, 2006). This plethora of different motivators is further extended with the food factor. Generation $Y$ consumes wine during meals because wine creates a special ambience when combined with food. This is consistent with previous work (Thach \& Olsen, 2004; Dubrow, 1992) that wine as a food enhancement is present as a motivator in wine consumption. In addition, the findings of Olsen et al. (2007) also support the fact that customers mainly agree that wine and food go together and enhance one another. This characteristic is found to be present in different age cohorts.

\subsection{Hypotheses Testing and Discussion}

Relationships between different wine consumption occasions and the identified motivators are tested. It is assumed that in different occasions diverse motivators should be expressed. Multivariate regression analysis was used, as we wanted to test the relationships between one dependent metric variable (wine consumption occasions) and four independent variables (wine consumption motivators). Therefore, because three separate wine consumption occasions are examined, three different multivariate regression analyses are conducted. As differences between genders are also posited to influence wine consumption occasions, separate analyses for both males and females were conducted. The Enter method was used for entering independent 
variables into the model. The results of the multivariate regression analyses are presented in the following tables (Table 3, 4 and 5).

In analyzing the model tested, several characteristics can be noticed. When considering the consumption of wine with friends for both females $(\beta=0.378)$ and males $(\beta=0.380)$, sociability is found to be the influencing factor. In addition, males are also under the positive influence of the food factor when consuming wine with friends $(\beta=0.165)$.

When analyzing wine consumption with a partner or family, the impact of the food factor is evident, while other wine consumption motivators do not contribute in situations where wine is consumed with a partner or family. Therefore, an individual's decision to consume wine with their partner/family influences the belief that wine enhances the taste of food. Nonetheless, the impact is somewhat higher for males $(\beta=0.398)$ than for females $(\beta=0.359)$.
The analysis of special occasions in wine consumption shows a different pattern. For females sociability is found to be the influencing factor $(\beta=0.214)$ when females consume wine on special occasions. At the same time, for males the sample food factor has influence $(\beta=0.221)$ on consuming wine on special occasions. Hence, when taking into account special occasions like a prom party or business occasions females and males differ in what motivates them to consume wine.

An analysis of the regression residuals was also done for subsamples. The assumption of random errors and homoscedasticity has been met. This is also true for the assumption of the normality of residuals, because the graphs show a normal distribution pattern. Tolerance and VIF were at acceptable levels. Several other tests for analyzing residuals were also done. Analysis reveals that Durbin-Watson test values are at acceptable levels. Cook distances are below

Table 3. Results of Multivariate Regression Analysis for Wine Consumption Occasions (Friends)

\begin{tabular}{|c|c|c|c|c|c|c|}
\hline & \multicolumn{3}{|c|}{ Model $1(F)$} & \multicolumn{3}{|c|}{ Model $2(\mathrm{M})$} \\
\hline & B & beta & t-value & B & beta & t-value \\
\hline Constant & $3.079^{* *}(0.270)$ & & 11.397 & $2.838^{\star \star}(0.356)$ & & 7.970 \\
\hline Self-expression & $-0.093(0.104)$ & -0.063 & $-0,894$ & $0.108(0.138)$ & 0.084 & 0.788 \\
\hline Sociability & $0.345^{\star *}(0.067)$ & 0.380 & 5.154 & $0.252^{* *}(0.094)$ & 0.378 & 2.670 \\
\hline Tradition & $-0.122(0.067)$ & -0.133 & -1.831 & $-0.102(0.107)$ & -0.108 & -0.954 \\
\hline Food & $0.096(0.064)$ & 0.110 & 1.488 & $0.165^{\star}(0.081)$ & 0.221 & 2.041 \\
\hline Observations & \multicolumn{3}{|c|}{194} & \multicolumn{3}{|c|}{101} \\
\hline $\mathrm{R}^{2}$ & \multicolumn{3}{|c|}{0.163} & \multicolumn{3}{|c|}{0.165} \\
\hline$R^{2}$ (adj) & \multicolumn{3}{|c|}{0.145} & \multicolumn{3}{|c|}{0.131} \\
\hline $\mathrm{F}$ & \multicolumn{3}{|c|}{$9.176^{* *}$} & \multicolumn{3}{|c|}{$4.755^{\star *}$} \\
\hline Effect size $\left(\mathrm{f}^{2}\right)$ & \multicolumn{3}{|c|}{0.195} & \multicolumn{3}{|c|}{0.195} \\
\hline Power & \multicolumn{3}{|c|}{0.999} & \multicolumn{3}{|c|}{0.955} \\
\hline
\end{tabular}

Note: $\mathrm{F}=$ female, $\mathrm{M}=$ male; ${ }^{*}{ }^{* *}$ significant at $<0.05,<0.001$ level respectively; standard errors are given in parenthesis; power is calculated at 0.05 level.

Dependent variables: My consumption of wine is mostly related to friends.

Table 4. Results of Multivariate Regression Analysis for Wine Consumption Occasions (Partner/family)

\begin{tabular}{|c|c|c|c|c|c|c|}
\hline & \multicolumn{3}{|c|}{ Model $1(F)$} & \multicolumn{3}{|c|}{ Model $2(\mathrm{M})$} \\
\hline & B & beta & t-value & B & beta & t-value \\
\hline Self-expression & $-0.031(0.143)$ & -0.016 & -0.218 & $0.284(0.182)$ & 0.158 & 1.562 \\
\hline Sociability & $0.062(0.092)$ & 0.050 & 0.669 & $-0.156(0.125)$ & -0.124 & -1.253 \\
\hline Tradition & $-0.037(0.092)$ & -0.030 & -0.409 & $0.186(0.141)$ & 0.142 & 1.318 \\
\hline Food & $0.425^{\star *}(0.089)$ & 0.359 & 4.791 & $0.413^{* *}(0.107)$ & 0.398 & 3.855 \\
\hline Observations & & 194 & & & 101 & \\
\hline $\mathrm{R}^{2}$ & & 0.136 & & & 0.242 & \\
\hline $\mathrm{R}^{2}$ (adj) & & 0.117 & & & 0.210 & \\
\hline $\mathrm{F}$ & & $7.420^{* *}$ & & & $7.642^{\star *}$ & \\
\hline Effect size $\left(\mathrm{f}^{2}\right)$ & & 0.195 & & & 0.319 & \\
\hline Power & & 0.997 & & & 0.998 & \\
\hline
\end{tabular}

Note: $\mathrm{F}=$ female, $\mathrm{M}=$ male; ${ }^{*},{ }^{*}$ significant at $<0.05,<0.001$ level respectively; standard errors are given in parenthesis; power is calculated at 0.05 level.

Dependent variables: My consumption of wine is mostly related to my partner/family 
Table 5. Results of Multivariate Regression Analysis for Wine Consumption Occasions (Special occasions)

\begin{tabular}{|c|c|c|c|c|c|c|}
\hline & \multicolumn{3}{|c|}{ Model 1 (F) } & \multicolumn{3}{|c|}{ Model $2(\mathrm{M})$} \\
\hline & B & beta & t-value & B & beta & t-value \\
\hline Self-expression & $-0.003(0.132)$ & -0.002 & -0.021 & $0.101(0.128)$ & 0.058 & 0.540 \\
\hline Sociability & $0.262^{* *}(0.085)$ & 0.214 & 3.078 & $0.106(0.187)$ & 0.086 & 0.825 \\
\hline Tradition & $-0.063(0.085)$ & -0.057 & -0.742 & $0.225(0.145)$ & 0.176 & 1.554 \\
\hline Food & $-0.004(0.082)$ & -0.004 & -0.045 & $0.223 *(0.110)$ & 0.221 & 2.034 \\
\hline Observations & & 194 & & & 101 & \\
\hline $\mathrm{R}^{2}$ & & 0.054 & & & 0.159 & \\
\hline$R^{2}$ (adj) & & 0.034 & & & 0.124 & \\
\hline $\mathrm{F}$ & & $2.702 * *$ & & & $4.552^{* *}$ & \\
\hline Effect size $\left(f^{2}\right)$ & & 0.057 & & & 0.189 & \\
\hline Power & & 0.758 & & & 0.946 & \\
\hline
\end{tabular}

Note: $\mathrm{F}=$ female, $\mathrm{M}=$ male; $^{*}{ }^{* *}$ significant at $<0.05,<0.001$ level respectively; standard errors are given in parentheses; power is calculated at 0.05 level.

Dependent variables: My consumption of wine is mostly related to special occasions

the acceptable cut-off of 1 and average leverage values for residuals are below a less stringent criterion (Field, 2009). The number of cases that fall outside -+2 and -+2.5 standardized residuals is in the ratio between $1-3 \%$ of the cases for the male and female subsamples, respectively. Hence, all subsamples conform fairly accurately to the model. Mahalanobis parameters were also below the cut-off point for smaller samples. DFBetas for both the male and female subsamples have values below 1; therefore, no cases will have any influence over the regression parameters.

It should be noted that all of the models explain a relatively low adjusted $R^{2}$ indicating that other factors should be considered and included in the model. Nonetheless, power analysis reveals that models exhibit relatively high power, such that type II error is relatively low (Field, 2009). It can be concluded that the researched factors have an influence on different wine consumption occasions.

From the analysis it is evident that Generation $Y$ exhibits different motivators in different wine consumption occasions. Sociability is the motivator of wine consumption for both males and females when consuming wine with friends. For the male subsample food also represents an influencing factor in this consumption occasion. This is consistent with the findings of Olsen et al. (2007) that reference groups, such as friends, are influential factors that support and induce wine consumption.

When consuming wine with a partner/family, both the male and female subsamples experience the food factor as a motivator. Therefore, wine is consumed with partners or family because of its characteristic of enhancing the taste of food. This finding supports previous results (Dubrow, 1992; Brunner \& Siegrist, 2011) indicating that wine and food go together for all individuals across different cohorts.

Wine consumption in special occasions is influenced by the sociability factor. This sociability factor is expressed only in the female subsample. Dubrow (1992) reports similar results that identify sociability as the most important factor in occasion-based consumption. Furthermore, in their research, Olsen et al. (2007) emphasize that at celebrations Generation $Y$ are the ones that mostly consume wine. Also interesting is the finding that the food factor has an influence on males when special occasions are analyzed.

Therefore, it can be concluded that Generation $Y$ exhibits different motivators that drive wine consumption. These motivators do differ depending on the wine consumption occasion, and different motivators are exhibited due to gender differences. As a result, it can be concluded that both of the posited hypotheses, $\mathrm{H} 1$ and $\mathrm{H} 2$, are confirmed.

\section{IMPLICATIONS, LIMITATIONS AND FURTHER RESEARCH}

This paper contributes to the recognition of situational and gender influences on wine consumption motivators. Different motivators of wine consumption are found to be present within Generation Y. The results of this research allow us to infer key factors that wine producers should consider in developing a constructive relationship with a local Generation Y. First, respecting gender differences when building wine marketing mix elements, especially in developing communication with target segments of Generation $\mathrm{Y}$, is important. In planning promotional activities wine producers should use different promotional messages targeting females and males. Moreover, creating a communications message with emphasis on different situations of wine consumption is needed as wine consumption motivators are diverse and situation-specific. By using these insights wine producers would benefit as a more adequate reach of the target market segment is ensured. Second, group dynamics should be used to reach young consumers and enhance the sociability element in relationships. The sociability element is found to be influential in most wine consumption 
occasions. By appreciating and inducing group dynamics among young customers wine consumption can be increased. Third, education regarding wine consumption should be provided in order to increase the awareness, capacity and confidence with which Generation $Y$ evaluates wine products and combines them with food. By offering diverse educational programmes for inexperienced wine consumers their knowledge about food-wine combinations can be enlarged. As a consequence they will feel more confident in consuming wine with food and experience hedonic pleasures more often. The pleasure perception should be used to study the specific elements of wine, in order to meet the hedonistic expectations of this target group, which are driven by their sensory, psychological and social values.

Fourth, in order to influence and develop wine's image, wine producers should take into account different wine consumption drivers and emphasize those that enhance the desired wine image. Combining the sociability factor and an emphasis on group dynamics, as well as reference groups such as consuming wine with friends in a friendly atmosphere can bring about a desirable, friendly image for wine. Alternately, if wine producer aims to build its image based on hedonic pleasures it can emphasize consuming wine with a partner or family as well as emphasizing that wine enhances the taste of different food combinations.

Furthermore, even if wine production in researched countries is at a low level compared to wine producing countries such as France and the USA, its importance in boosting economic development is immense. Based on specific regional segmentation and the local character of wine production it is important not to neglect this agricultural activity as it induces local and regional development. Generational issues are, however, only one element that marketers should include in planning their marketing strategies (Higgins, 1998). Qualitative research to explore previous consumption behaviour would help to provide a deeper explanation of the findings.

The limitations of this study primarily concern its limited sample size and the sampling method that was used. Also, a relatively limited number of wine consumption motivators are included. In addition, the sociability factor exhibits a somewhat lower AVE value (0.44) and therefore should be tested on a different sample.

Further research should focus on identifying the wine consumption motivators of other age cohorts and how they differ with Generation Y. Also, more wine consumption motivators and consumption locations should be included in the research to obtain more profound knowledge about the wine consumption patterns of Generation Y. This topic will greatly benefit from qualitative research on identifying motivators that were neglected or omitted in previous research. Moreover, combining qualitative research will help also to explore new wine consumption patterns that will offer new insights for wine producers. Further research could also concentrate on researching the wine consumption motivators of Generation $Y$ among different religious groups and to identify their influence on wine consumption patterns.

\section{REFERENCES}

Anderson, J.C., \& Gerbing, D.W. 1988. Structural equation modelling in practice: A review and recommended two-step approach. Psychological Bulletin, 103(3): 411-423.

ASBH - Agency for Statistics of Bosnia and Herzegovina, 2013. Women and men in Bosnia and Herzegovina, thematic bulletin. Sarajevo: Agency for Statistics of Bosnia and Herzegovina.

Atkin, T., Nowak, L. \& Garcia, R. 2007. Women wine consumers: information search and retailing implications. International Journal of Wine Business Research, 19(4): 327-339.

Brunner, T.A. \& Siegrist, M. 2011. A consumer-oriented segmentation study in the Swiss wine market. British Food Journal, 113(3): 353-373.

Bruwer J., Saliba A. \& Miller B. 2011. Consumer behaviour and sensory preference differences: implications for wine product marketing. Journal of Consumer Marketing, 28(1): 5-18.

Bruwer, J. 2004. The love affair of Generation-X consumers with the winery tasting room. The Australian \& New Zealand Grapegrower \& Winemaker, 491: 19-24.

CBS - Croatian Bureau of Statistics, 2013. Statistical Yearbook of the Republic of Croatia 2013. Zagreb: Croatian Bureau of Statistics.

Charters S., Velikova N., Ritchie C., Fountain J., Thach L., Dodd T.H., Fish N., Herbst F. \& Terblanche N. 2011. Generation Y and sparkling wines: a cross-cultural perspective. International Journal of Wine Business Research, 23(2): 161-175.

Charters, S. 2006. Wine and Society, Oxford: Elsevier Butterworth-Heinemann.

Diamantopoulos, A., \& Siguaw, J. (2000). Introducing LISREL, London: SAGE publications.

Dubow, J.S. 1992. Occasion-based vs. user-based benefit segmentation: a case study. Journal of Advertising Research, 32(2): 11-18.

EC - European commission, 2012. Agriculture in the European Union statistical and economic information 2011. Brussels: Commission Directorate- General for Agriculture and Rural Development.

Euromonitor International 2010a. Wine - Bosnia-Herzegovina Country Sector Briefing. London: Euromonitor International.

Euromonitor International 2010b. Wine - Croatia Country Sector Briefing. London: Euromonitor International.

Euromonitor International, 2012. Wine in Croatia-Country Report. London: Euromonitor International.

FAO - Food and agriculture organization, 2012. The wine sector in Bosnia and Herzegovina. Budapest: Regional Office for Europe and Central Asia Food and Agriculture Organization of the United Nations (FAO). http://www.fao.org/fileadmin/user_upload/Europe/documents/Publications/IPARD_BiH/5Wine_ en.pdf (accessed May 20, 2014)

Field, A. 2009. Discovering statistics using SPSS, $3^{\text {rd }}$ edition. London: Sage publications.

Fornell, C., \& Larcker, D.F. 1981. Evaluating structural equation models with unobservable variables and measurement error. Journal of Marketing Research, 18(1): 39-50.

Gain report, 2014. Global agricultural informational network, USDA Foreign Agricultural service. Zagreb: American Embassy, Foreign Agricultural Service. http://gain.fas.usda.gov/ Recent\%20GAIN\%20Publications/Wine\%20Report_Zagreb_ Croatia_2-20-2014.pdf (accessed May 21, 2014)

Garst, J. \& Bodenhausen, G.V. 1997. Advertising's effects on men's gender role attitudes. Sex Roles, 36(9/10): 551-572. 
Gunay G.N. \& Baker M.J. 2011. The factors influencing consumers' behaviour on wine consumption in the Turkish wine market. EuroMed Journal of Business, (6)3: 324-341.

Hair, J.F. Jr., Black, W.C., Babin, B.J., Anderson, R.E., \& Tatham, R.L. 2006. Multivariate Data Analysis, 6th edition. Upper Saddle River, N.J.: Pearson Prentice Hall.

Hoffman, C.A. (2004). When consumers buy wine, what factors decide the final purchase?. Australian and New Zealand Wine Industry Journal, 19(2), 82-91.

http://ec.europa.eu/agriculture/statistics/agricultural/2012/pdf/ c1-1-31_en.pdf (accessed May 21, 2014)

Inglehart, R. 1997. Modernization and Postmodernization: Cultural, Economic, and Political Change in 43 Societies. Princeton, NJ: Princeton University Press.

Kevany, S. 2008. French Millennials drinking less, Americans more. Meninger's Wine Business International, 3: 13-17.

Kolyesnikova, N., Dodd, T.H. \& Duhan, D.F. 2008. Consumer attitudes towards local wines in an emerging region: a segmentation approach. International Journal of Wine Business Research, 20(4): 321-334.

Kotler, P. \& Keller K. 2008. Marketing Management, 13th edition, Prentice Hall.

Lancaster, L.C. \& Stillman, D. 2002. When Generations Collide: Who They Are. Why They Clash. How to Solve the Generational Puzzle at Work. New York: Harper Business.

MacKenzie, S.B., Podsakoff, P.M., \& Podsakoff, N.P. 2011. Construct measurement and validation procedures in MIS and behavioral research: Integrating new and existing techniques. MIS Quarterly, 35(2): 293-334.

Mueller, S., Remaud, H. \& Chabin, Y. 2011. How strong and generalisable is the Generation $Y$ effect? A cross-cultural study for wine. International Journal of Wine Business Research, (23)2: 125-144.

Nielsen, 2007. Millennial consumers seek new tastes, willing to pay a premium for alcoholic beverages, News release from the Nielsen Company, available at: www.nielsen.com

OIV, 2012. Statistical report on world vitiviniculture, 2012. Paris: International organization of Vine and Wine.

Olsen, J.E., Thach, L. \& Nowak, L. 2007. Wine for my generation: exploring how US wine consumers are socialized to wine. Journal of Wine Research, (18)1: 1-18

Peskett, S. 2006, Under-30s are the big spenders in UK market, Harpers, 26 May: 10.

PWC- PricewaterhouseCooper, 2013. PwC's NextGen: A global generational study Millennial Workers Want Greater Flexibility, Work/ Life Balance, Global Opportunities. PricewaterhouseCooper.
http://www.pwc.com/en_GX/gx/hr-management-services/ pdf/pwc-nextgen-study-2013.pdf (accessed May 21, 2014)

Quester, P.G. \& Smart, J. 1996. Product involvement in consumer wine purchases: its demographic determinants and influence on choice attributes. International Journal of Wine Marketing, 8(3): 37-56.

Ritchie, C. 2009. The culture of wine buying in the UK off-trade. International Journal of Wine Business Research, 21(3): 194 - 211.

Robinson, J. 2004. A woman's place is in the cellar, San Francisco Chronicle, 8 July.

Schamberg, A. 2002. Battle of the sexes plays out in wine. Milwaukee Journal Sentinel, 18 August.

Spawton, T. 2000. A taxonomy of wine consumer research in Australia 1990-2000, paper presented at the XXIVeme Congress of Wine and Vine, Paris.

Stanford, L., Bailey, P. \& Rowley, J. 2008. Market insights: Australia, Wine Industry Outlook Conference Supply and Demand Report. Adelaide: Australian Wine and Brandy Corporation.

Teagle, J., Mueller, S. \& Lockshin, L. 2010. How do Millennials' wine attitudes and behaviour differ from other generations? Proceedings 5th International Academy of Wine Business Research Conference, 8-10 February 2010, Auckland, NZ. Academy of Wine Business Research.

Thach, E. \& Olsen, J. 2004. The search for new wine consumers: marketing focus on consumer lifestyle or lifecycle?, International Journal of Wine Marketing, 16(3): 44-57.

Thach, E.C. \& Olsen, J.E. 2006. Market segment analysis to target young adult wine drinkers, Agribusiness, 22(3): 307-322.

US Department of State, 2010. Bosnia and Herzegovina. US department of state - Bureau of democracy, human rights, and labour. http://www.state.gov/j/drl/rls/irf/2010/148920.htm (accessed May 21, 2014)

Vrontis, D. and Papasolomou, I. 2007. Brand and product building: the case of the Cyprus wine industry. Journal of Product \& Brand Management, 16(3): 159-167.

WHO - World health organization, 2014. WHO Global Status Report on Alcohol and Health 2011. Geneva: World health organization. http://www.who.int/substance_abuse/publications/global_alcohol_report/msb_gsr_2014_3.pdf (accessed May 20, 2014)

Wine Intelligence 2010. Generation wine: Getting to the heart of Millennial wine drinker around the world, paper presented at the London International Wine Fair LIWF, London, 18 May.

World bank group, 2014. Agriculture, value added (\% of GDP). Washington: World Bank's Development Data Group. http:// data.worldbank.org/indicator/NV.AGR.TOTL.ZS/countries (accessed May 21, 2014) 